\title{
An Economical Evaluation of the Water/Steam Injection in a CHP Microturbine Cycle
}

\author{
D. N. Loujendi*, K. A. Sani, A. A. Tofigh, A. Majidian and H. J. Jouybari \\ Dpt of Mechanical Engineering, Islamic Azad University, Takestan Branch, Takestan, Iran.
}

Received 14 January 2012; Accepted 20 August 2012

\begin{abstract}
In this paper we study the economical evaluation of injecting the water/steam into the micro gas turbine (MT) cycle witch operate in combined heat and powercycle. Heat and electricity cogeneration is a way for optimizing energy consumption. Cogeneration power plants produce both electric and thermal from one energy source. These systems could work by different movers but one of the most important and applied prime movers are Microturbine. Microturbines are small electricity generators which their producted electric power is $25-350 \mathrm{~kW}$ and their efficiency is almost $18 \%$ that can reach to $30 \%$ approximately by use of recuperator in their cycle. By water/steam injection into the MT cycle, the power will be enhanced and its efficiency will be changed too.

The fundamental aim of this study is economic evaluation of outfit the MT cycle to water/steam injection system. Here after the presentation of cogeneration systems, there are explanations of Microturbines and a thermodynamic analysis has been shown. Then the experimental and simulation results of water and steam injection to the different points in the cycle were compared. At last the economic evaluation of these cases and the energy production cost of any system were evaluated by Matlab codes. However injection increase the produced power, but according to the energy and set prices, the injection to the system is not economical. Non-injected system have the least payback (6 year) and its energy production cost is $0.043 \$ / \mathrm{kWh}$. But between the injection cases, water injection into the combustor is preferable choice that has 7.1 year as capital payback period, the least energy production cost $(0.054 \$ / \mathrm{kWh})$ and $(-89.8 \$)$ disadvantage (decrease in net incomes) respect to Dry in compare to other case of injection.
\end{abstract}

Keywords: Economical evaluation, Cogeneration, Microturbine, Water and steam injection.

\section{Introduction}

Electricity and heat cogeneration systems are those which generate both electricity (axial power) and thermal energy by using energy from one prime source. Thermal power is obtained through regenerating the thermal losses existing in the exhaust hot gasses and it is used as hot water or steam in different sections of the industrial, commercial and residential buildings. Cogeneration was presented in Europe and America in the last 1880s so that about 58 percent of the total generated power was produced as cogeneration in America at the first decade of 1900 s. With the notable increase in the fuel cost at the year 1974 and following that the emergence of a crisis to the energy, these systems which have higher energy efficiency, were taken into consideration more. The efficiency of the current conventional systems in localized way is about 27 to 55 percent that the most efficiency of it is belong to the combined cycle power plants while the energy efficiency of cogeneration systems even reaches to 80 percent. The most important components of the cogeneration power plants are their prime movers from which the most useable ones are reciprocating engines, gas turbines, steam turbines and fuel cells. Microturbines are also placed at the gas turbines class. The main difference

\footnotetext{
*E-mail address:nemati_danial@yahoo.co.uk

ISSN: 1791-2377 @ 2012 Kavala Institute of Technology. All rights reserved.
}

between movers involves their type of used fuel, combustion process, total efficiency, the amount and temperature Degree of exhaust energy. In [5] energy consumption and pollutant propagation of CHP systems was compared with conventional systems and $12.1 \%$ saving in prime energy was reported. In [6] 2.6\% decrease in annual energy costs due to use of CHP system was reported.[7,8] was reported economic advantage of micro $\mathrm{CHP}$ in residential and commercial buildings. In $[9,10]$ the results related to the evaluation of different kinds of movers have been reported. In [15] a MT was examined from different viewpoint domestic and industrial customer and the result was achieved that using the MT for exclusive use is superior to buying electricity from network. In [11] a CHP MT was evaluated under four different plans and it is also evaluated its using by heat pomp or using only for a residential building at Tehran and the use of this MT for electric load generation and a portion of thermal loud was known as the most optimum. Reference [12,16] also report an example of economic evaluation of CHP system. In one study recently an economic evaluation of a $500 \mathrm{~kW}$ MT which was used for a hospital of 250 bedsteads in order to provide thermal and electric load that as a result of it, the capital payback period was computed about 9.5 year. The economic evaluation has been also reported by Capstone company related to the use of a $30 \mathrm{~kW}$ MT for 200 commercial consumers and recuperated and non-recuperated Microturbines have been compared from an economic viewpoint. In reference [17] it 
has been carried out a technical, economic and environmental evaluation of CHP MT for different industries and the capital payback years has been computed.

\section{Microturbines}

Microturbines are small electricity generators which burn gaseous or liquid fuel and rotate an electric generator. Microturbines examination was started from 1997 and it was applied in the commercial use in 2000. The power generation range of developing Microturbines is usually below $500 \mathrm{~kW}$. Low Manufacturing costs, higher efficiency, lower noise, quick operation and low emission have made this technology successful to the extent it has become one of the most popular choice for using in heat and power cogeneration on the scale of commercial uses. In Fig. 1 you can see different parts of MT. In the more advanced cycles, Microturbines transmit some of the exhaust gases heat into the air by using of recuperator and thus MT electric efficiency is increased by 25 to 33 percent.

Microturbines have simple structures because of having one rotator axis which turbine and compressor are installed on it. Microturbines in CHP mode transmit the heat of the exhaust gas (which has been passed from recuperator before) into the water by a heat exchanger. At below a thermodynamic analysis has shown the pure produced power and consumed heat by the recuperated microturbine.

$w_{n e t}=w_{T}-w_{C}$

$w_{n e t}=C_{P, g} \cdot \eta_{T} \cdot T_{4} \cdot\left[1-\frac{1}{r_{P} \frac{\gamma_{g}-1}{\gamma g}}\right]-\frac{C_{P, a}}{\eta_{c}} \cdot T_{1} \cdot\left[r_{P}^{\frac{\gamma_{a-1}}{\gamma a}}-1\right]$

The net thermal energy that consumed by system is:

$Q_{n e t}=Q_{c c}-Q_{r e c}=C_{P, g}\left[\left(T_{4}-T_{2}\right)-\varepsilon\left(T_{5}-T_{2}\right)\right]$

$Q_{n e t}=C_{P, g} \cdot\left[T_{4}-T_{1}(1-\varepsilon)\left[1+\frac{r_{P}^{\frac{\gamma a-1}{\gamma a}}-1}{\eta_{C}}\right]-\varepsilon \cdot T_{4}[1-\right.$

$\left.\left.\eta_{T}\left[1-\frac{1}{r_{P}^{\frac{\gamma g-1}{\gamma g}}}\right]\right]\right]$

That $\varepsilon$ is effectiveness of recuperatorat last, thermal efficiency calculated by relation (5):

$\eta_{t h}=\frac{w_{n e t}}{Q_{n e t}}$

By use of relation mentioned above, the influence of ambient temperature on the performance of this microturbine in different effectiveness of recuperator is shown in Fig. 2.

\section{The injection of water and steam to the cycle}

Ambient conditions have a big effect on the MT operation in a way that we face intense power and efficiency drop in the high temperature. The elevation from sea level will decrease its exhaust power too [3].
One propounded method for optimizing energy consumption and decreasing undesirable effects of ambient conditions is to inject water or steam into the cycle. Water and steam injection can be done to the different points in the cycle. Four case of water and steam injection to the combustor and recuperator inlet have been examined.

In all four modes of injection, system power will be enhanced because of the increase in working fluid mass flow rate while the fuel Consumption of the system will also be enhanced. Power enhancement is to the extent that thermal efficiency of the cycle will also be enhanced at all modes except the water injection to the combustor (WI-C). In Table 1 the summaries of operational data of injected and noninjected MT cycles have been compared [4].

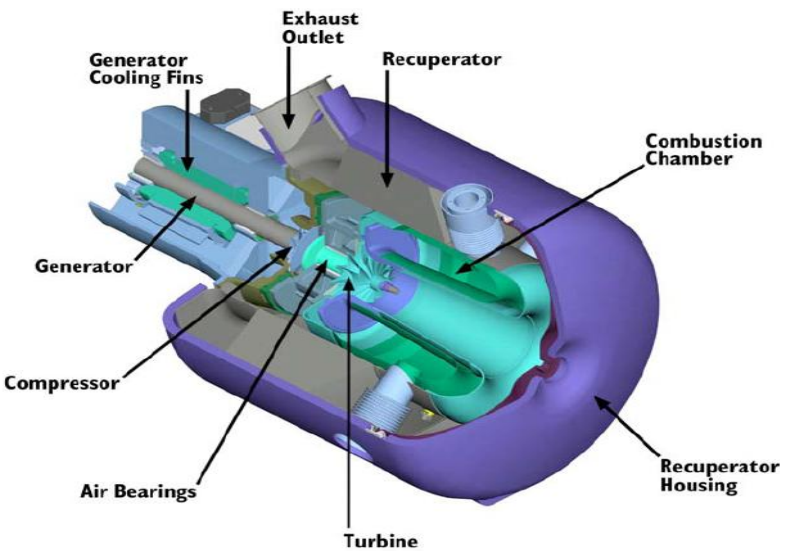

Fig. 1. Components of MT.

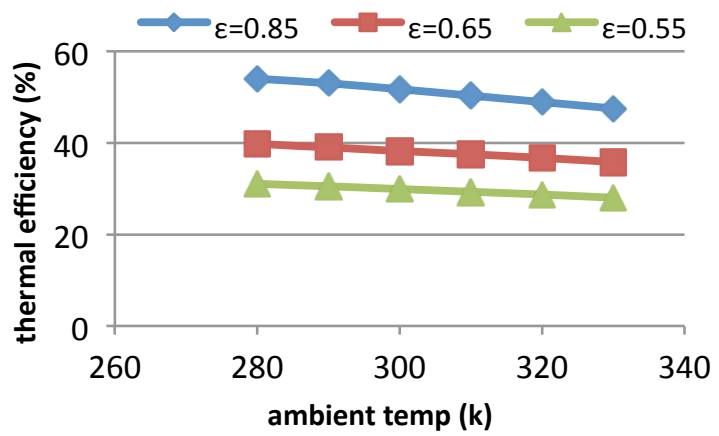

Fig. 2a. Effect of ambient temperature on the performance of MT in different effectiveness of recuperator.

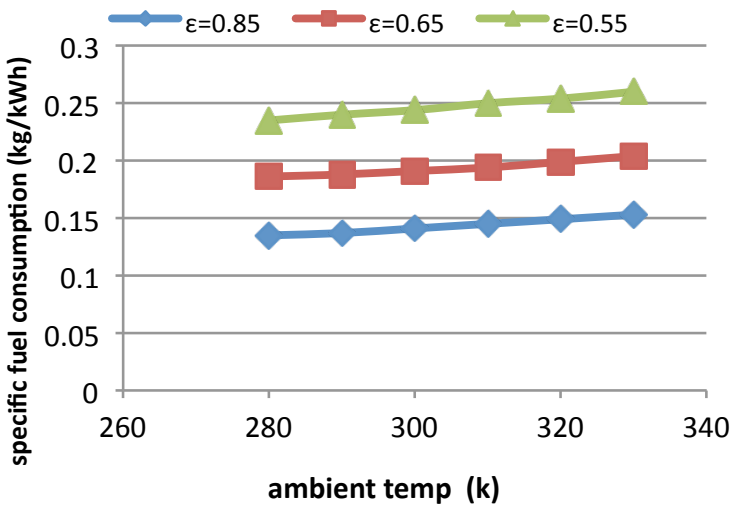

Fig. 2b. Effect of ambient temperature on the fuel consumption of MT in different effectiveness of recuperator. 
Table 1. Summary of operational data of MT in different mode

\begin{tabular}{|c|c|c|c|c|c|}
\hline & Dry & SI-R & SI-C & WI-C & WI-R \\
\hline Air flow rate & 0.2685 & 0.2657 & 0.2652 & 0.2642 & 0.2645 \\
\hline $\begin{array}{l}\text { Rate of water/steam } \\
\text { generation }(\mathrm{kg} / \mathrm{s})\end{array}$ & 0.1600 & 0.0128 & 0.0150 & 0.2069 & 0.0831 \\
\hline $\begin{array}{l}\text { Rate of } \\
\text { injection }(\mathrm{kg} / \mathrm{s})\end{array}$ & - & 0.0128 & 0.0150 & 0.0180 & 0.0180 \\
\hline $\begin{array}{l}\text { Rate of fuel flow } \\
(\mathrm{kg} / \mathrm{s})\end{array}$ & 0.00205 & 0.00228 & 0.00246 & 0.00353 & 0.00253 \\
\hline System power $(\mathrm{kW})$ & 22.62 & 27.15 & 28.04 & 29.67 & 29.17 \\
\hline $\begin{array}{l}\text { Change of the system } \\
\text { power from dry } \\
\text { operation mode }(\%)\end{array}$ & - & 20.0 & 24.0 & 31.2 & 29.0 \\
\hline System efficiency(\%) & 22.3 & 24.21 & 23.15 & 17.09 & 23.47 \\
\hline $\begin{array}{l}\text { Change of the system } \\
\text { efficiency from dry } \\
\text { operation mode }(\%)\end{array}$ & - & 8.6 & 3.8 & -23.4 & 5.3 \\
\hline Thermal power $(\mathrm{kW})$ & 44.66 & 0 & 0 & 52.75 & 18.17 \\
\hline
\end{tabular}

Prime Energy Saving (PES):

In comparison with the conventional separated heat and power generation systems "PES" is an important economic factors which is representative of saving rate in prime energy by CHP systems. PES was described as relation (6) by European energy parliament in 2004.

$$
\text { PESPES }=1-\frac{1}{\frac{\eta_{e l}}{\eta_{e l, r e f}}+\frac{\eta_{t h}}{\eta_{t h, r e f}}}
$$

The positive amounts of this factor means that the prime energy consumption in CHP system is less than single generation systems [13].

The "ref" index in this relation is related to the conventional single heat and electricity generation systems that the amount of their thermal and electric efficiency is nearly 30 and 70 percent respectively. The saving rate is seen on Table 2. The conclusion which is realized from these tables among injected systems, only the water injection to the combustor saves its consumption of prime energy too little in comparison with the conventional systems.

- The Economic comparison of CHP MT equipped with injected system with dry operation system:

In this part of study, we're going to compare a MT in dry operation mode with several types of injected ones. Here the investor is supposed to utilize cogeneration system as a small private power plant and sells its electric and thermal power. The important point here is that investor intends to select one choice among 5 packages of CHP MT (one dry case and four injection cases). It means the packages are equipped with injection system beforehand.

\section{- Capital payback period:}

For computing capital payback period, it is necessary to compute annual incomes and costs and also prime costs in nth year after installation. Then according to relation, we compute the capital payback period for each case by considering that incomes and costs to be equal.

Table 2. The PES values

\begin{tabular}{llllll}
\hline & DRY & WI-R & WI-C & SI-R & SI-C \\
\hline PES \% & 27.30 & -0.94 & 0.30 & -23.91 & -29.58 \\
& & & & & \\
\hline
\end{tabular}

\section{- Prime capital cost:}

Prime capital cost computed according to relation (7)

$C C_{i n v}[\$]=C C_{i n v, u}[\$ / K w] \times E_{n o m}[K w]$

That CCinv is amount of prime cost in exchange for per $\mathrm{kW}$ of generated electric power of MT and for the non-injected system is $1300 \$ / \mathrm{kW}$ [11]. Furthermore about $150 \$ / \mathrm{kW}$ is increased to the prime cost of dry system by adding injection system and this amount is equal to $1450 \$ / \mathrm{kW}[1]$. $\mathrm{E}_{\mathrm{nom}}$ is also nominal power of MT and is equal to $30 \mathrm{~kW}$ in this study. The prime investment cost in nth year after installation is computed according to relation (8) that $\mathrm{n}$ is the year that the engine operates and iis annual average interest rate and it is equal to $10 \%$.

$C C_{i n v}^{n}[\$]=C C_{i n v}[\$] \times(1+i)^{n}$

\section{- Income of electric power selling:}

Annual income of selling the electric power to the network is computed according to relation (9) that in it $\mathrm{P}_{\mathrm{el}}$ is electric power and $\mathrm{T}_{\mathrm{op}}$ is the time of annual operation of system which is supposed to 8640 hours in a year. $\mathrm{C}_{\mathrm{el}}$ is the price of selling $1 \mathrm{kWh}$ electricity to the network and according to the reliable contract of ministry of power is almost equal to $0.05 \$$. After installation, the annual income rate in nth year is computed by relation (10).

$$
\begin{aligned}
& I_{e l}[\$]=P_{e l}[K w] \times C_{e l}\left[\frac{\$}{K w h}\right] \times T_{o p}[h] \\
& I_{e l}^{n}[\$]=I_{e l}[\$] \times\left(\frac{(1+i)^{n}-1}{i}\right)
\end{aligned}
$$

\section{- Income of thermal power selling:}

Investor earns income by selling generated Thermal of system to the network that its annual rate is computed as follows:

$I_{t h}[\$]=P_{t h}[K w] \times C_{t h}\left[\frac{\$}{K w h}\right] \times T_{o p}[h]$

In this relation $\mathrm{C}_{\mathrm{th}}$ is the price of one $\mathrm{kWh}$ thermal power selling that its estimatal amount is $0.014 \$$. Thus, the income of heat power in the nth year is computed as follow relation

$I_{t h}^{n}[\$]=I_{t h}[\$] \times\left(\frac{(1+i)^{n}-1}{i}\right)$

\section{Used fuel cost}

The cost of used fuel for each system during annual operation and its equivalence in the nth year of installation are computed with relation (13) and (14) respectively.

$$
\begin{aligned}
& C C_{f}[\$]=\dot{m}_{f}\left[\frac{\mathrm{kg}}{\mathrm{s}}\right] \times \frac{1}{\rho_{g}} \times 3600 \times T_{o p}[h] \times C_{f}\left[\frac{\$}{\mathrm{~m}^{3}}\right] \\
& C C_{f}^{n}[\$]=C C_{f}[\$] \times\left(\frac{(1+i)^{n}-1}{i}\right)
\end{aligned}
$$

In this relation, $\dot{m}_{f}$ is the fuel rate and $\rho_{g}=0.714$ is the gas density. $\mathrm{C}_{\mathrm{f}}$ is the price of one cube meter of natural gas. According to the gas company tariff the average price for per cube meter of gas delivered to the power plant is $0.076 \$$ but by considering 20 percent reduction of fuel price to the small power plant, its price will be equal to $C_{f}=0.06 \$$. 


\section{Cost of annual used water}

The cost of annual used water through CHP system is computed as follows:

$$
C C_{w}[\$]=\dot{m}_{w}\left[\frac{\mathrm{kg}}{\mathrm{s}}\right] \times \frac{1}{\rho_{w}} \times 3600 \times T_{o p}[h] \times C_{w}\left[\frac{\$}{\mathrm{~m}^{3}}\right]
$$

and $\rho_{w}$ are the rate and density of water respectively, that the amount of density is $\rho_{w}=1000, C_{w}$ is the price of one cube meter of water that according to the tariff amount of it is equal to $0.047 \$$ averagely. The annual cost of water in the nth year after installation is computed with the relation (16).

$C C_{w}^{n}[\$]=C C_{w}[\$] \times\left(\frac{(1+i)^{n}-1}{i}\right)$

\section{- Operation and maintenance costs:}

Almost 2 percent of the prime investment cost is averagely used for annual amount of this cost [11]. Thus annual amount and its equivalence in the nth year are computed according to the relation (17) and (18).

$C C_{o \& m}[\$]=0.02 \times C C_{i n v}$

$C C_{o \& m}^{n}[\$]=C C_{o \& m}[\$]\left(\frac{(1+i)^{n}-1}{i}\right)$

After computing incomes rate and costs of each one of systems in nth year of installation, for computing capital payback period, we should consider costs and incomes to be equal. It means the capital payback period is the time when incomes will be equal to the costs.

$C C_{i n v}^{n}+C C_{f}^{n}+C C_{w}^{n}+C C_{o \& m}^{n}=I_{t h}^{n}+I_{e l}^{n}$

The summary of economic results of these systems is shown in Table 3.

The economical evaluation of the use of steam injection system in the MT for only electric power generation:

Although the use of MT in cogeneration has more economical profit in comparison to the state that electric power is only considered, but the evaluation to the use of steam injection system in this state is not ungraceful [4]. The capital payback period is evaluated through the division of prime cost on annual net benefit of system and result shown in Fig. 3 [9].

Table 3. The summary of economic results of systems

\begin{tabular}{|c|c|c|c|c|c|}
\hline SI-C & SI-R & WI-C & WI-R & $\overline{D R Y}$ & $\begin{array}{l}\text { Operation mode } \\
\text { Cost or income }\end{array}$ \\
\hline 43500 & 43500 & 43500 & 43500 & 39000 & Prime cost[\$] \\
\hline 12413 & 3.12019 & 9.13134 & 5.12913 & 9.10013 & $\begin{array}{l}\text { Annual income of } \\
\text { selling the electric } \\
\text { power [\$] }\end{array}$ \\
\hline 0 & 0 & 4.6337 & 9.2182 & 4.5365 & $\begin{array}{l}\text { Annual income of } \\
\text { selling the thermal } \\
\text { power [\$] }\end{array}$ \\
\hline 9.6531 & 0.6054 & 1.9373 & 8.6717 & 3.5434 & $\begin{array}{l}\text { Annual cost of } \\
\text { used fuel[\$] }\end{array}$ \\
\hline 2.22 & 9.18 & 3.391 & 1.123 & 237 & $\begin{array}{l}\text { Annual cost of } \\
\text { used water [\$] }\end{array}$ \\
\hline 870 & 870 & 870 & 870 & 780 & $\begin{array}{l}\text { Annual cost of } \\
\text { operation and } \\
\text { maintenance [\$] }\end{array}$ \\
\hline 9.4988 & 4.5076 & 9.8837 & 5.7385 & 8928 & $\begin{array}{l}\text { Net annual } \\
\text { incomes[\$] }\end{array}$ \\
\hline 3.21 & 4.20 & 1.7 & 3.9 & 6 & Capital payback \\
\hline
\end{tabular}

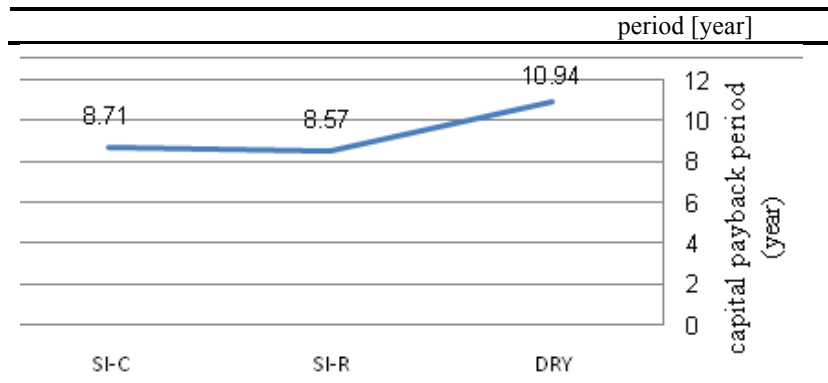

Fig. 3. Capital payback period

The sensibility evaluation of system:

Among different parameters using in economic evaluation of energy projects, mostly the parameter related to the price are not announced exactly bye the producer or they can be different depending on the project condition. Also the experts have always squabbles on the price of types of energy and fuel and their accuracy will have great influence on the result of the computations. Thus the parameter related to the price of projects in different strategies should be evaluated in term of the sensibility in order to generalize the obtained result and also to meet the expert opinion.

The sensibility of the system toward the price of electricity selling:

Because of high generation of electric power, each one of these systems can show high sensibility toward the increase or decrease of electricity price.

The graph in Fig. 4 shows that two steam injection systems have high sensibility toward the increase of electricity price, because their outlet is only electric power in a way that for example if the price of electricity increases by 1.5 times, their capital payback period will be decreased to $\frac{1}{4}$ of previous amount.

\section{Sensibility toward the MT set prices:}

Whit considering the decision of the companies producing MT on reduction in total price of the system, in this part the influence of increase or decrease of the price on the capital payback period has been evaluated. Both increase and decrease of prime price of the system has been spot in this evaluation. You can see the results of this evaluation in the following Figures.

The above graphs are representative of high sensibility of the system toward the fluctuation of prime price of the system. Fig (5) has been shown sensibility of the MT capital payback toward the fluctuation of prime set price.

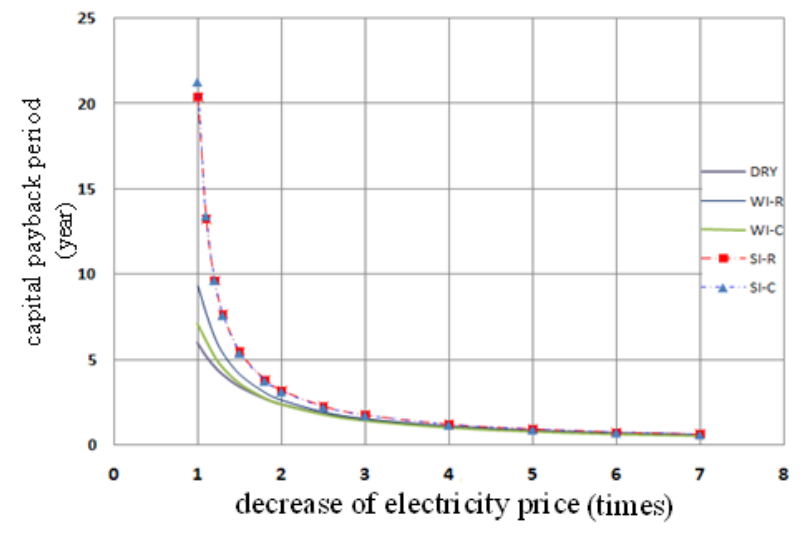


Fig. 4. Sensibility toward the increase in electricity price.

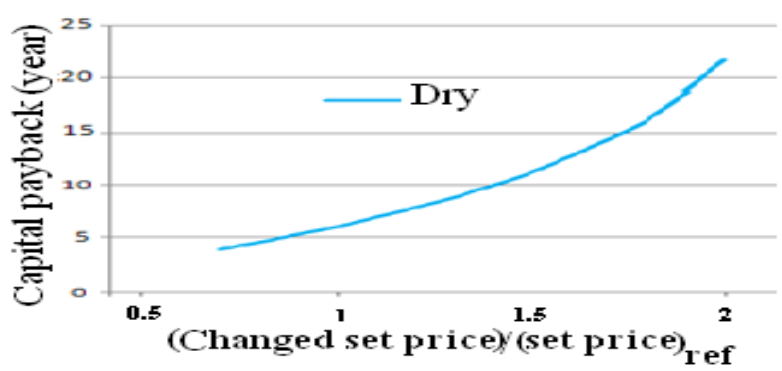

Fig. 5a. Sensibility toward the set price changes.

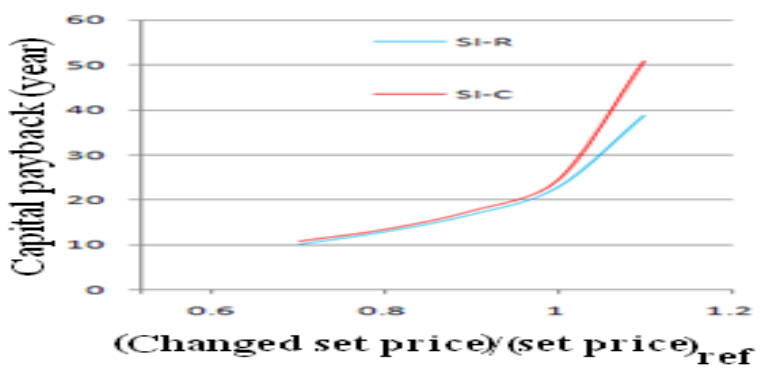

Fig. 5.b Sensibility toward the set price changes.

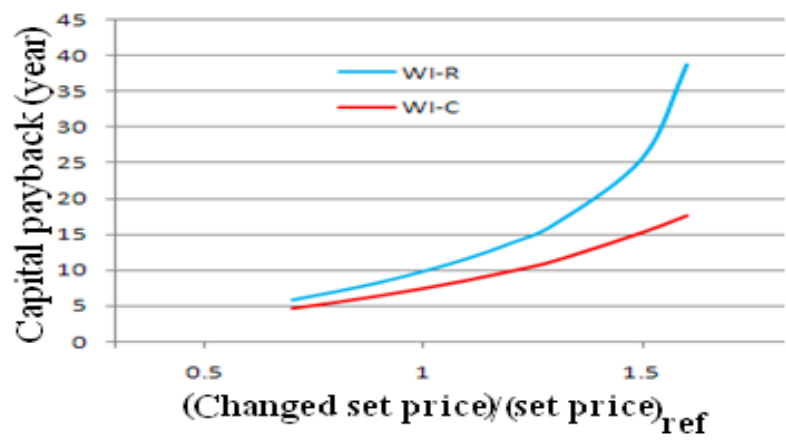

Fig. 5.c. Sensibility toward the set price changes

-Sensibility toward the fluctuation of the fuel price:

The fuel price of each country can have high influence on the current costs of a power plant. As we saw on Table 3, the fuel cost has the greatest proportion on the annual costs of the system. The sensibility toward the fluctuation of the fuel price is seen in the following graphs. These graphs are representative of high sensibility of the steam injection toward the fluctuation of the fuel price too. Fig. 6 has been shown sensibility of the MT capital payback toward the fluctuation of fuel price.

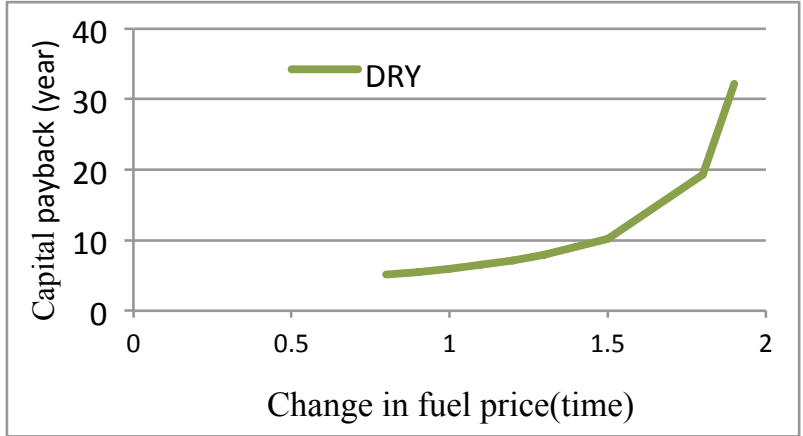

Fig. 6.a. Sensibility toward the fuel price changes.

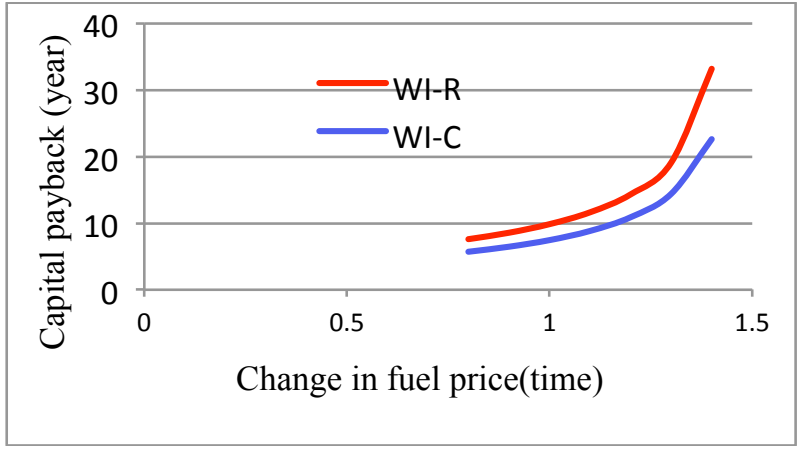

Fig. 6.b Sensibility toward the fuel price changes.

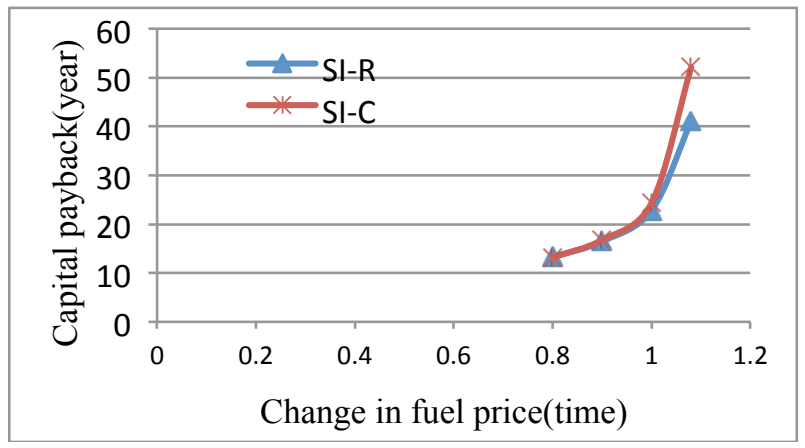

Fig. 6.c. Sensibility toward the fuel price changes.

Considering figures and results related to the sensibility of the systems toward each one of the effective factors and with the use of the superposition law, we can simply evaluate total influence of three factors on the MT for different operation mode of dry or injection mode and under several sets.

Results of this section are shown in Table 4.

Table 4. Life cycle cost analysis results.

\begin{tabular}{|c|c|c|c|c|c|}
\hline SI-C & SI-R & WI-C & WI-R & DRY & \\
\hline 43500 & 43500 & 43500 & 43500 & 39000 & $\begin{array}{l}\text { Present } \\
\text { worth of } \\
\text { capital } \\
\text { costs }[\$]\end{array}$ \\
\hline 23316 & 23316 & 23316 & 23316 & 20904 & $\begin{array}{l}\text { Present } \\
\text { worth of } \\
\text { O\&M } \\
\text { costs [\$] }\end{array}$ \\
\hline 175054 & 162247 & 251199 & 180037 & 145639 & $\begin{array}{l}\text { Present } \\
\text { worth of } \\
\text { fuel costs } \\
{[\$]}\end{array}$ \\
\hline 595 & 506 & 10486 & 3299 & 6351 & $\begin{array}{l}\text { Present } \\
\text { worth of } \\
\text { water cost } \\
{[\$]}\end{array}$ \\
\hline 242465 & 229569 & 328501 & 250152 & 211894 & $\begin{array}{l}\text { Life cycle } \\
\text { cost }[\$]\end{array}$ \\
\hline 28491 & 27008 & 38647 & 29429 & 24899 & $\begin{array}{l}\text { annual life } \\
\text { cycle cost } \\
\text { [\$/year] }\end{array}$ \\
\hline 0.117 & 0.115 & 0.054 & 0.072 & 0.043 & $\begin{array}{l}\text { cost of } \\
\text { energy } \\
\text { production } \\
{[\$ / \mathrm{kWh}]}\end{array}$ \\
\hline
\end{tabular}


Table 5. List of used legend

\begin{tabular}{|c|c|c|c|}
\hline \multicolumn{2}{|c|}{ power $C H P$} & price & $C$ \\
\hline Mass flow rate & $\dot{m}$ & $\begin{array}{l}\text { Water injection in } \\
\text { recuperator }\end{array}$ & $W I-R$ \\
\hline microturbine & $M T$ & $\begin{array}{l}\text { Water injection in } \\
\text { combustor }\end{array}$ & $W I-C$ \\
\hline efficiency & $\eta$ & $\begin{array}{l}\text { Steam injection in } \\
\text { recuperator }\end{array}$ & $S I-R$ \\
\hline $\begin{array}{l}\text { Low heat valu } \\
\text { fuel }\end{array}$ & $L H V$ & $\begin{array}{l}\text { Steam injection in } \\
\text { combustor }\end{array}$ & $S I-C$ \\
\hline Thermal power & $\dot{Q}$ & Dry operation & $D R Y$ \\
\hline power & $P, E, \dot{W}$ & income & $I$ \\
\hline Prime energy sa & $P E S$ & $\operatorname{cost}$ & $C C$ \\
\hline
\end{tabular}

Table 6. List of used indices.

\begin{tabular}{ll|ll}
\hline $\begin{array}{l}\text { Heat recovery } \\
\text { unit }\end{array}$ & $H R U$ & simulation & sim \\
Mechanical & $m e c$ & Examination & test \\
Recuperator & $r e c$ & loss & aux \\
Reference & $r e f$ & Operation & $o p$ \\
Fuel & $f, f u e l$ & Shaft & $s h$ \\
Combuator & $c c$ & Water & $w$ \\
Compressor & $c$ & electric & $e l$ \\
Turbine & $T$ & thermal & $t h$ \\
Gas turbine & $G T$ & operation and & $o \& m$ \\
& & maintenance & \\
Generator & $g e n$ & Investment & $i n v$ \\
\hline
\end{tabular}

\begin{tabular}{ll|ll}
\hline microturbine & $M T$ & Unit & $u$ \\
\hline
\end{tabular}

\section{Conclusion}

As you see in this part of using injection system for MT was analysed by different viewpoints and approaches economically and the results were provided and reviewed. All injecting modes improve electric power and all of them are pernicious for investor. Systems which operate in dry mode due to costs and energy price strategies mentioned and their shorter capital payback period are economically better to be choosed. Also the most economic choice among the injection equipped systems is the WI-C that have 7.1 year as payback period and WI-R is the next proffer. By injecting the steam, system converts from cogeneration state to single production thus outfit the cogeneration MT to steam injection system is not commodious but according to the second part of this analysis if we intend to add an injection system to a cogeneration microturbine, still the injecting water in combustor has the shortest capital payback and the least disadvantage respect to the dry operation. Also dry systems and WI-R have the lowest cost of energy production among these systems. Though SI-R has shorter capital payback period in compare to SI-C but none of them is economic. But in case microturbine is just used for electric power production the one with steam injection in recuperator is superior and has the most advantage.

\section{References}

1. Meherwan, P. Boyce, "Gas Turbine Engineering Handbook" Elsevier, 2006.

2. Tuccillo.R, "Performance and Transient Behavior of MGT Based Energy Systems", Napoli University, 2007.

3. "Catalog of CHP Technologies", U.S. Environmental Protection Agency, 2008.

4. Lee. J. J, Joen. M. S, Kim. T. S, "The Influence of Water and Steam Injection on the Performance of Recuperated Cycle Micro Turbine for Combined Heat and Power", Appl Energy, 2010, 1307-1316.

5. Mago.P. J, Hueffed. A. K, "Evaluation of a Turbine Driven CCHP System for Large Office Buildings Under Different Operating Strategies", Engineering and Buildings, 2010, 1625-1636.

6. Ren. H, Gao. W, "Economic and Environmental Evaluation of Micro CHP Systems with Different Operating Modes for Residential Buildings in Japan”, Energy and Building, 2010, 853861

7. Arthur. D, "Cooling, Heating and Power (CHP) for Commercial Buildings Benefits Analysis”, U.S. Department of Energy, 2002.

8. U. S. Department of Energy, ORNL, "Feasibility Screening for Combined Heat and Power in Multifamily Housing”, U. S. Department of Housing Urban Development, 2009.

9. Fumo. N, Pmago. J. P, Chamra. M. L, "Energy and Economic Evaluation of Cooling, Heating and Power System Based of Primary Energy", APPL Thermal Engineering 29, 2009, 26652671.

10. Bailey. O, Ouaglal. B, Bartholomew. E, Marnay. C, Bourassa., "An Engineering - Economic Analysis of Combined Heat and Power Technologies in a Mgrid Application", Betkeley National Laboratory, 2002.

11. Ehyaei.M.A, Mozafari. A, "Energy, Economic and Environmental (3E) Analysis of Micro Gas Turbine Employed for On-Site Combined Heat and Power Production" Energy and Buildings
2010, 259-264.

12. Sirim, Maznah.A.M, "Case Studio on the Economic and Financial Viability of Natural Gas-Fired CHP Projects", CHP Energy Service, 2005.

13. Caresana.F, Comodi.G, Pelagalli.L, Vagni.S, "Micro Gas Turbine", Italy Department of Energy, 2009.

14. Crawford. P, McAllister. K, Lupo. T, "Clean Heat and Power Option for Charlotte Mecklenburg UtlilitesMcAlpine Creek Waste Water Treatment Facility", North Caroline Solar Center, 2007.

15. Siahkali. H, Heidari. K, "Economic Evaluation of Microturbine Utilization from Customers Viewpoint", Nineteenth International Electricity Conference, Iran, 2004.

16. Gholami. A, MirrezaeeRoodaki. S. J, ghazi zade. M. S, "Economic Evaluation and Sensibility Analysis of CCHP Systems for Residential Apartment in Tehran", Twenty Fifth International Electricity Conference, Iran, 2010.

17. ZamaniNejad. M, Makarizade. V, Salimian. Z, Shakeri. O, "Appointment of Effective Indicators of Electricity and Heat Cogeneration in Country Industries and their Preference on this Base", Twenty Fifth International Electricity Conference, Iran, 2010.

18. Sanaye. S, Safari. H. R, "Technical and Economic Evaluation of the Use of Absorptive and Compress Systems for Cooling the Gas Turbine Air" Eighth International Electricity Conference, Iran, 2004.

19. Sanaye. S, Fardad. A, Ebrahimi.M, "Technical and Economic Evaluation of Cooling and Evaporative Methods for Gas Turbine Inlet Air", Eighth international Electricity Conference, Iran, 2004.

20. Amiri. A. H, Zand. A, "Engineering Economy", Department of Industries Engineering, Iran, 2010.

21. Malhotra. V, "Life Cycle Cost Analysis of Novel Cooling \& Power Gas Turbine Engine", University of Florida, 2005. 